\title{
Improvement of boiler efficiency by recovering latent heat
}

\author{
○正土本信孝内山清彰 ((株) タクマ) \\ Nobutaka TSUCHIMOTO, Kiyoaki UCHIYAMA (TAKUMA Co., LTD.)
}

\begin{abstract}
Nowadays, reduction of $\mathrm{CO}_{2}$ emissions is one of the most important problem in Japanese industry with respect to global warming. The improvement of boiler efficiency is the most effective for reduction of $\mathrm{CO}_{2}$ emissions in industry boiler field compared with other $\mathrm{CO}_{2}$ reduction technologies.

The heat loss by flue gas is the major part in the total heat loss of the boiler. The natural gas has increased to be used for small boilers recently. It is easy to recover waste heat from flue gas of boiler. It contains about 15 vol. $\%$ of $\mathrm{H}_{2} \mathrm{O}$ gas in flue gas of natural gas-fired boiler. So, we can get substantial improvement in boiler efficiency by recovering not only the sensible heat, but also the latent heat from the flue gas.
\end{abstract}

Key Words: Natural Gas, Reduction of $\mathrm{CO}_{2}$ Emissions, Condensing Boiler, Latent Heat

1. はじめに

地球環境負荷低減、とくに $\mathrm{CO}_{2}$ 低減に関し、産業用およ び民生用ボイラの熱効率向上は重要な課題となっている。 ボイラにおける最も大きな熱損失は排ガスによって大気に 放出される排気損失である。近年、環境負荷低隇のためボ イラ用燃料として都市ガス (天然カスス) が多く使われるよ うになり、排ガスからの熱回収もしやすくなり、現状でも かなりの高効率（87〜96\%）となっている。しかし、都市カ スの燃鈥排カスには多量の水蒸気が含まれており、顕熱と ともに水蒸気の凝縮潜熱を回収すれば、ボイラ効率の大幅 な改善が得られる。

本稿では潜熱回収型多管貫流ボイラの性能特性とエコ ノマイザーにおける熱伝達特性および物質伝達特性につい て述べる。

2. ボイラ設備仕様

最近の小型ボイラ（多管貫流ボイラ）は省エネ時代のニー ズに応えて高効率化が進んでおり、午体だけのもので 87〜 89\%、エコノマイザー付きのもので 94〜 96\%が一般的な仕様 となっている。このように比較的高効率なボイラの効率を 更に向上させるためには、燃焼排カス中の水蒸気の凝縮熱 まで利用する潜熱回収型システムが必要不可欠となる。潜 熱回収を伴わないボイラでは排ガス温度の回収は80〜 $90^{\circ}$ Cが限界であり、ボイラ効率はせいぜい 95〜96\%くらい である。これに対し、給水温度を低くして管表面温度を排 ガスの凝縮温度以下にすれば、顕熱とともに潜熱も回収可 能となり、ボイラ効率の大幅な改善が得られ、低位発熱量 基準で 100\%を越えることも可能である。しかし、都市ガス $13 \mathrm{~A}$ の燃焼排ガスの凝縮ドレンは $\mathrm{pH}$ が約 3.5 の酸性を示し、 伝熱管およびケーシングに腐食耐久性が求められる。また、 生成した凝縮ドレンをスムーズに落下・排出させるため、 水平伝熱管に上下流排ガスの構造をとる必要がある。

実験に用いた潜熱回収型高効率俕イラは午体、顕熱回収 エコノマイザー、潜熱回収エコノマイザー、およびその他 補機類で構成され、スリムで多缶設置対応型となっている。 表 1 にボイラ設備の、表 2 にエコノマイザーの主要目を示 す。
Table 1 Particulars of Boiler

\begin{tabular}{|l|c|}
\hline Boiler Model & TWGN-2000LE \\
\hline Type & Multi-tube \\
\hline Equivalent Evaporation & $2.000 \mathrm{~kg} / \mathrm{h}$ \\
\hline Thermal Output & $1.253 \mathrm{~kW}$ \\
\hline Maximum Pressure & $1.0 \mathrm{MPa}$ \\
\hline Working Pressure & $0.7 \mathrm{MPa}$ \\
\hline Steam Temperature & Saturated \\
\hline Thermal Efficiency & $101 \%$ \\
\hline Heating Surface & $9.65 \mathrm{~m}^{2}$ \\
\hline Water Level Control & $0 \mathrm{n}-0 \mathrm{ff}$ \\
\hline Combustion Control & High-Low-0f f \\
\hline Fuel & LNG $13 \mathrm{~A}$ \\
\hline
\end{tabular}

Table 2 Particulars of Economizer

\begin{tabular}{|l|l|l|}
\hline & High Temp. Eco. & Low Temp. Eco. \\
\hline Configuration & Vertical Tube and & Spiral Tube and \\
& Horizontal Gas Flow & Vertical Gas Flow \\
Tube Type & Serrated Fin Tube & Solid Fin Tube \\
Tube Material & Carbon Steel & SuS304 \\
Tube Diameter & 27.2 mm & 27.2 mm \\
Heating & $16.8 \mathrm{~m}^{2}$ & $38.1 \mathbf{m}^{2}$ \\
Surface & & \\
\hline
\end{tabular}

\section{3。ボイラ性能特性}

潜熱回収ボイラの性能は、潜熱回収エコノマイザーでの 凝縮部の大きさによって影響を受ける。すなわち、給水温 度が低いほど凝縮部が大きくなり、顕熱回収量、潜熱回収 量とも増加し、ボイラ効率は向上する。

図 1 に最大燃焼時で空気比 1.2 の時の給水温度をパラメー タにしたボイラ性能特性を示す。排カスからの凝縮量（ド レン量）は、給水温度が低いほど多く、排気温度は、給水 温度が低いほど低くなる。その結果として、給水温度が低 いほどボイラ効率は高くなる特性を持つ。給水温度が $50^{\circ} \mathrm{C}$ にもなると凝縮水の排出は見られなくなり、伝熱管表面で は凝縮現象が生じてなく、全体が顕熱回収エコノマイザー として作用することになる。 

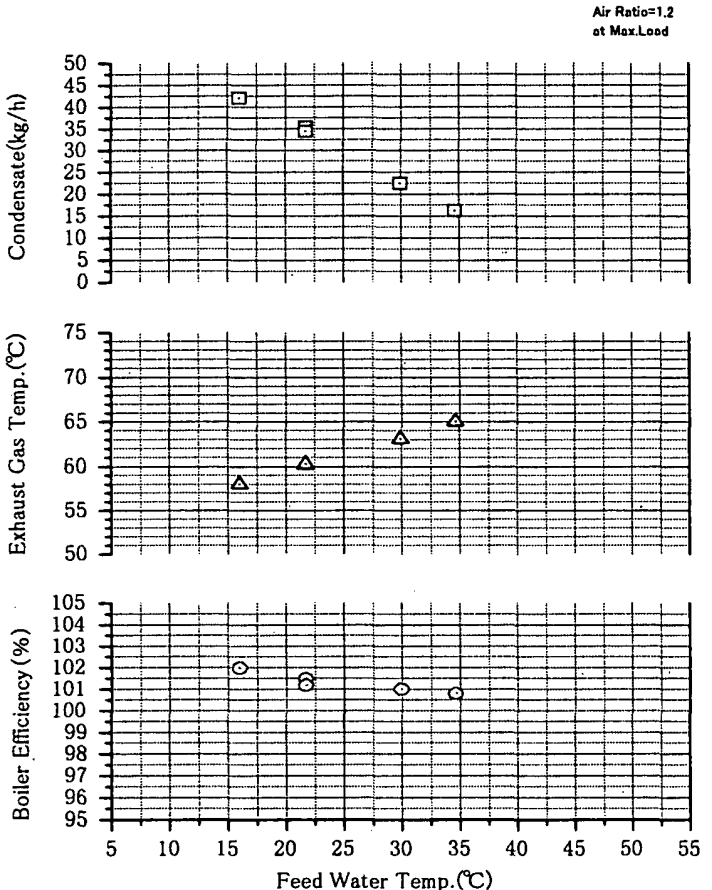

Fig. 1 Performance Characteristics

4. 熱伝達特性および物質伝達特性

図 2 は、エコノマイザーにおけるフィン付き伝熱管の熱 伝達および物質伝達特性に関する実験結果を示す。図中の 口印、 $\triangle$ 印の実験点は、それぞれ顕熱回収エコノマイザー および潜熱回収エコノマイザーの顕熱部における対流伝熱 のみの熱伝達特性を示す。○印は、凝縮現象が生じてい る対流伝熱と物質伝達の共存域での熱伝達特性を示す。

図中の一点鎖線は、次式によるフィン付き伝熱管群の熱 伝達に関する実験式に基づく計算值を示す。

顕熱回収エコノマイザーに対し：

$\mathrm{Nu}=0.166 *(\mathrm{Fb}+\mathrm{Ff} * \eta \mathrm{f}) * \mathrm{Re}^{0.618} * \mathrm{Pr}^{0.31}$

潜熱回収エコノマイザーに対し；

$\mathrm{Nu}=0.188 *(\mathrm{Fb}+\mathrm{Ff} * \eta \mathrm{f}) * \mathrm{Re}^{0.603} * \mathrm{Pr}^{0.31}$

ここで、 $\mathrm{Nu}:$ ヌッセルト数 $(\mathrm{hg} * \mathrm{~d} / \lambda)$

$\operatorname{Re}:$ レイノルズ数 $(\mathrm{Vg} * \mathrm{~d} / \nu)$

$\operatorname{Pr}:$ プラントル数 $(\mathrm{Cp} * \nu * \gamma / \lambda)$

$\mathrm{Fb}$ : フィン付き管のベアー部の面積割合

Ff：フィン付き管のフィン部の面積割合

$n \mathrm{f}:$ フィン効率

一方、物質伝達特性については、図中のく印が潜熱回 収エコノマイザーの実験点を示し、図中の 2 点鎖線は、 熱伝達と物質伝達のアナロジーが成り立つとした場合の 次式による実験式に基づく計算値を示す。

$$
\begin{aligned}
\mathrm{Sh}=0.188 *(\mathrm{Fb}+\mathrm{Ff} * \eta \mathrm{f}) * \mathrm{Re}^{0.603} * \mathrm{Sc}^{0.31} \\
\text { ここで、Sh : シャーウッド数 (hm*d/D) } \\
\mathrm{Sc}: \text { シュミット数 }(\nu / \mathrm{D})
\end{aligned}
$$

凝縮現象が生じていない顯熱回収部においては、熱伝達 特性に関する実験值（口印、 $\Delta$ 印）と式 (1)、式 (2) で 示す実験式による計算値とが良く一致している。しかし、 ドレン生成がみられる潜熱回収部においては、実験値（○ 印）と式（2）による計算値との間に若干の食い違いがみ られるが、落下凝縮液膜により対流伝熱が阻害されている のではないかと推測される。

一方、物質伝達特性に関する実験値（ $\diamond$ 印）は、式（3） の対流伝熱とのアナロジーによる予測計算值よりも約 $20 \%$ 下回っており、水平伝熱管に水平ガス流れの実験によ る結果 (1)と異なる特性になっている。しかし、これは凝縮 水量を潜熱回収量のベースとしたためであり、20\%程度の凝 縮水の再蒸発が生じていると考えるのが妥当である。
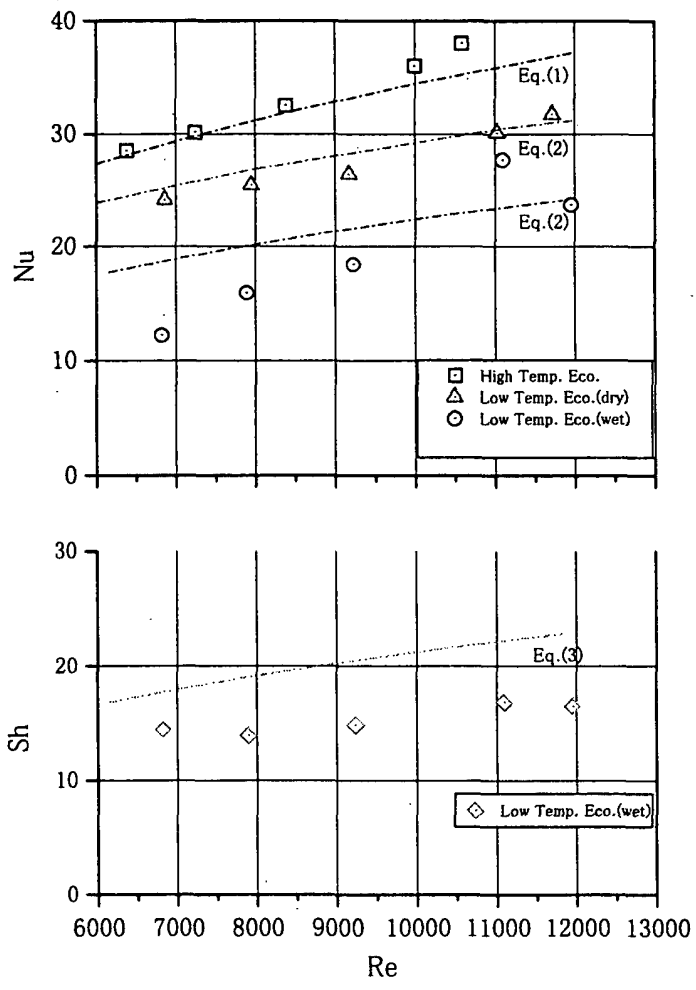

Fig. 2 Characteristics of Heat \& Mass Transfer

5. おわりに

現在生産されている産業用ボイラ（小型ボイラ含む）の ボイラ効率は 87〜96\%と高いレベルにあるが、設㯰台数は、 労働省統計によるボイラだけでも約 6 万 7 千台 ${ }^{(2)}$ と多く、 産業用ボイラのエネルギー消費量は製造分野で消費される エネルギーの約 $21 \%{ }^{(3)}$ を占め、潜熱回収ボイラ等のさら なる高性能化による $\mathrm{CO}_{2}$ 削減効果は大きい。

参考文献

(1) 神坂、ほか 4 名、「排ガスからの水分回収に関する研究」、 日本機械学会論文集 58 巻 545 号 (1992)

（2）（財）日本ボイラ協会、「ボイラー年鑑、平成 11 年度版」(2000)

(3) 通商産業大臣官房調査統計部、平成 10 年石油等 消費構造統計速報（1999） 